\title{
New Leaders, Same Problems: The Conservatives
}

Link to publication record in Manchester Research Explorer

\section{Citation for published version (APA):}

Green, J., \& Cowley, P. (2005). New Leaders, Same Problems: The Conservatives. In Britain Decides: The British General Election of 2005 Palgrave Macmillan Ltd.

\section{Published in:}

Britain Decides: The British General Election of 2005

\section{Citing this paper}

Please note that where the full-text provided on Manchester Research Explorer is the Author Accepted Manuscript or Proof version this may differ from the final Published version. If citing, it is advised that you check and use the publisher's definitive version.

\section{General rights}

Copyright and moral rights for the publications made accessible in the Research Explorer are retained by the authors and/or other copyright owners and it is a condition of accessing publications that users recognise and abide by the legal requirements associated with these rights.

\section{Takedown policy}

If you believe that this document breaches copyright please refer to the University of Manchester's Takedown Procedures [http://man.ac.uk/04Y6Bo] or contact uml.scholarlycommunications@manchester.ac.uk providing relevant details, so we can investigate your claim.

\section{OPEN ACCESS}




\title{
4 \\ New Leaders, Same Problems: The Conservatives
}

\author{
Philip Cowley and Jane Green
}

Election night 2005 was the first for over 20 years in which the phrase 'Conservative gain' had been heard regularly on British TV and radio. Having effectively stood still in 2001 - when they had made a net gain of just one seat - the Tories ended the 2005 campaign up by a more respectable 33 seats. The Parliamentary Party increased in size by 20 per cent, the party won seats in the three countries of Great Britain for the first time since 1997, and (although not all their own work) they saw the government's majority fall from over 160 to a much more assailable 66. They also almost entirely repulsed the expected assault on Conservative seats from the Liberal Democrats. It was not just that the Liberal Democrats' much-discussed 'decapitation' strategy - targeting high-profile Conservative MPs in marginal seats - was a flop, but also that the Liberal Democrats' more general attack on Conservative marginal seats failed almost entirely. The Liberal Democrats took just three seats off the Tories, but lost five in return. In short, most Conservatives were feeling much more chipper when they woke up on 6 May 2005 than they had been four years previously.

But any Conservative who sprang out of bed filled with the joys of life had obviously not looked too closely at the election results. It was a sign of how bad things had got that the result could be seen as a success. Despite the increase in seats, 2005 remained the fourth worst Conservative performance at a general election for 100 years. Winning a total of 198 seats (including South Staffordshire) was a worse performance than Michael Foot's (frankly dismal) Labour Party had managed in 1983, and only the elections of 2001, 1997 and 1906 had seen the Tories win fewer seats. In share of the vote, the Tories gained just 0.6 per cent on 2001, itself thought to be a catastrophe, up to 32.3 per cent. This was a smaller increase than had been achieved by William Hague in 2001, and represented the third worst Conservative performance in terms of share of the vote for 100 years (beating only 1997 and 2001). In the North of England, 
the Conservative share of the vote actually fell; in other parts it increased just microscopically: up, for example, just 0.1 per cent in the Midlands, by just 0.2 per cent in Scotland. The electoral system rewarded the Conservatives' rather meagre improvement because in several key seats Labour's vote fell, not because there was any substantial Conservative revival. In London, for example, the reported swing 'to' the Conservatives of 4.9 per cent was caused much more by Labour's vote dropping 8.4 per cent than by the rather meagre increase of 1.4 per cent in the Conservative vote. Even in the South East, where the Tories did best, their share of the vote only went up by 2.1 per cent.

It was also the first time for almost 100 years that the Tories had lost three elections on the trot. At the beginning of the twentieth century, they had lost in 1906 and in two elections of 1910 - but by the end of those three elections (and in the space of just four years) they had achieved parity in terms of seats with the then government; by 1910, there were 272 Liberals, 272 Conservatives. The election of 2005 - eight years after their first landslide defeat - found the Conservatives still 158 seats behind Labour.

The period from 2001 to 2005 therefore constituted the journey from the third worst Conservative performance for 100 years to the fourth worst Conservative performance for 100 years. It had involved two different leaders - Iain Duncan Smith and Michael Howard - with Howard announcing the day after the 2005 election that he intended to resign the leadership. He thus became the fourth Conservative leader to have been seen off by Tony Blair and the third in a row not to make it to Prime Minister. Prior to William Hague, the party had only ever had one leader, Austen Chamberlain, who had failed to become Prime Minister. In the eight years from 1997, that figure increased to four.

This chapter is an examination of the attempts of the Conservative Party to improve its position under both Iain Duncan Smith (IDS) and Michael Howard. We show that whilst the change in leadership might have been necessary - and whilst it brought some benefits to the party's fortunes - the belief that a change in leadership could be sufficient to restore Conservative fortunes was always unrealistic: new leaders simply find themselves facing the same old problems. We begin with the selection of Iain Duncan Smith as party leader, and then discuss his performance in the role, and subsequent dismissal. We then examine Michael Howard's approach, and examine Conservative strengths and weaknesses during the election campaign. We highlight the obstacles the party must overcome if it is to return to being anything other than the natural party of opposition.

\section{The selection of IDS}

When Michael Howard announced, the day after the 2005 election, that he would be standing down as Tory leader, he also said that he would remain in post until the procedures for electing the party's leader had been reformed. There were two 
possible explanations for Howard delaying his resignation in that way. The first and more cynical explanation (denied, obviously, by Mr Howard) was that he was attempting to alter the rules in a way that would stymie those would-be leaders of whom he did not approve whilst giving an advantage to candidates he backed (David Davis was the name usually mentioned as an example of the former, with David Cameron being usually mentioned as an example of the latter). More generally, his move was believed to relate to the outcome at the beginning of the 2001 Parliament, when Iain Duncan Smith had emerged victorious.

The leadership rules had last been reformed under William Hague's leadership, giving the grassroots membership some involvement in the selection of the leader for the first time, and many MPs (along with plenty of commentators) blamed this innovation for Duncan Smith's success; the grassroots were accused of having selected IDS ahead of (what others argued were) more competent and electorally appealing candidates. The choice of IDS had demonstrated, so the argument went, the foolishness of giving the grassroots membership any significant say in choosing the leader. The grassroots chose IDS over Ken Clarke simply because the former shared their opinions (prejudices?) on Europe, rather than choosing a leader with the necessary skills. This has now become the widely accepted view of the 2001 leadership election - and is one of the key motivations of those who wanted to alter the leadership election rules after 2005.

It is, however, almost completely wrong. William Hague's reforms did end the Parliamentary Party's monopoly in leadership selection, but the parliamentarians remained extremely important, far more so than in other British political parties. The process involved the party's wider membership in the country, but only once the incumbent leader had resigned or been ejected by the MPs - at which point the wider membership were merely offered a choice between the two candidates most favoured by the Parliamentary Party. Indeed, there was no compulsion on the parliamentary party to put two candidates forward to the members at the final stage - as some more prescient observers pointed out at the time - and as came to pass.

Five candidates stood for the leadership in 2001: Ken Clarke, Iain Duncan Smith, Michael Portillo, Michael Ancram and David Davis. A multiple ballot system was used to choose the final two candidates to go through to the ballot of the party membership, with the bottom placed candidate being eliminated after each round.

Unfortunately the first round (see Table 4.1) saw two candidates - Davis and Ancram - share the wooden spoon, leading to the vote being held for a second time. The party's rules were widely criticised for not foreseeing such a possibility ('Can't they get anything right?', asked the Daily Mail; 'Chaos', said the Sun), with surprisingly little criticism focusing on the two candidates themselves for failing to withdraw from the race in the interests of the party, given their somewhat pitiful performance. The re-run contest, two days later, saw both Davis and 
Ancram lose votes, whilst the front three candidates improved their positions slightly. Ancram was then eliminated from the contest; Davis withdrew (albeit after initially attempting to stay in the running). Both urged their supporters to vote for Duncan Smith.

Table 4.1 Changes in support between rounds, 2001 Conservative Party leadership contest

\begin{tabular}{lccccc}
\hline & Round 1 & $\begin{array}{c}\text { Round 1 } \\
(\text { re-run })\end{array}$ & Change & Round 2 & Change \\
\hline Clarke & 36 & 39 & $(+3)$ & 59 & $(+20)$ \\
Duncan Smith & 39 & 42 & $(+3)$ & 54 & $(+12)$ \\
Portillo & 49 & 50 & $(+1)$ & 53 & $(+3)$ \\
Davis & 21 & 18 & $(-3)$ & - & - \\
Ancram & 21 & 17 & $(-4)$ & - & - \\
\hline
\end{tabular}

The second round proper saw Clarke top the poll (59 votes), followed by Duncan Smith (54). Portillo - who had been in front in the first two rounds, and who was widely seen as the frontrunner - came third by one vote and was therefore eliminated.

Portillo's problem was easily summed up. Unlike Hague (in 1997), or Clarke and Duncan Smith (in 2001), Portillo was unable to attract supporters from defeated candidates. As Table 4.1 shows, after the first round his support went up by just one vote (compared to three each for Clarke and Duncan Smith). In the second round - when Clarke's support went up by 20 and Duncan Smith's by twelve - Portillo's support went up by just three, and not enough to keep him in the race. He was almost no MP's second choice. Indeed, there was a sizeable group of Conservative MPs who wanted to stop Portillo at any cost. The size of Clarke's final lead - which surprised Clarke himself - was at least partly due to a handful of Duncan Smith supporters who, thinking that Duncan Smith was himself going to top the poll, decided to vote for Clarke in order to block Portillo. Too clever by half, their actions almost had disastrous consequences for their candidate. Portillo himself summed his problem up well: 'I seem to unite people against me in antagonism' (Walters 2001: 207).

The sources of this antagonism were various. Portillo suffered from accusations that he (or, more often, his aides, supporters and assorted hangers-on) had been disloyal to William Hague (and, prior to 1997, John Major). Such accusations appeared repeatedly during the campaign but these were merely the public manifestations of widespread ill-feeling amongst parts of the Parliamentary Party. As one of the key 'modernisers' within the party, and an advocate of symbolic liberal changes in the party's policies, he also suffered both from a sense amongst some MPs that he had shifted his beliefs (to the chagrin of those who had kept 
the faith) and - just as importantly - that there was still no clear sign of exactly what his new beliefs were. As one journalist put it to him when he addressed the Parliamentary Press Gallery on the day of the second ballot: 'Are you still on a journey or are you just refuelling?'

It is this ballot that is the source of the view that Clarke somehow won the MPs' ballot - and that the grassroots membership were therefore overruling, or overturning, the judgement of the party's (oh-so-wise) parliamentarians in selecting Iain Duncan Smith. Yet the ballot of MPs that Clarke led was a penultimate, not a final, ballot. Had the decision been left solely to Conservative MPs, with no subsequent ballot of the grassroots membership, Portillo would have been eliminated from the contest and there would then have been a final run-off between Clarke and IDS. In those circumstances, who knows where Michael Portillo's backers would have gone? It is far from certain that many of them would have gone to the pro-European Clarke; and it is therefore quite possible that IDS would have won any ballot confined solely to the party's MPs. Moreover, it was, as Peter Lilley pointed out in a letter to the Guardian (9 May 2005), Conservative MPs who had drawn up what he described as 'the dismal shortlist of Kenneth Clarke and Iain Duncan Smith' in the first place. If IDS really was so terrible a candidate, why had he managed to finish in the top two places?

There is equally little evidence that IDS emerged victorious from the resultant run-off between him and Clarke solely because of the zealotry of Conservative activists. It is clear from the surveys that were carried out that one fear that Conservative members had was that Clarke would not help the party present a united front: according to one survey, 60 per cent of Conservative members thought Clarke would split the party. To be sure, this is evidence of Clarke's views on Europe counting against him, but given that disunity is thought to be a certain vote-loser, the party members were making a more strategic decision than many gave them credit for. More anecdotally, Conservative grassroots members were also swayed by the performance of the candidates at the various hustings that were arranged; Clarke appeared under-prepared at several of the meetings, whereas IDS performed better at the hustings than many people had expected, receiving largely positive reviews.

There is therefore no evidence whatsoever that the grassroots membership somehow overruled the MPs in a fit of ideological zealotry. It is quite possible that the grassroots chose the same candidate that the MPs would have chosen, had they been forced to make that decision, and for the very same reasons.

\section{IDS as leader}

Equally misunderstood was IDS's strategy once he became leader. For many observers, the election of a right-wing Eurosceptic - and a former Maastricht 
rebel to boot - was proof that the Conservative Party would move further to the right, and become even more obsessed by Europe in the process.

This criticism proved wide of the mark. For sure, one of IDS's first acts as leader was to harden the party's European policy. Under Hague, the policy had been to rule out the euro for two Parliaments - effectively eight years. Under IDS, the party ruled out membership for good. IDS was helped in making this move by changes in the composition of the parliamentary party in the four years since Hague became leader, the number of pro-European Conservative MPs having diminished yet further at the 2001 election. But this hardening of policy was not a sign that the party was ever more obsessed about Europe; rather, the shift in policy was designed to ensure that the party did not spend any longer discussing the issue. By 'closing' the issue in this way - and by arguing that it should not be an issue for a general election but for any forthcoming referendum - IDS was determined to escape the criticism levelled at Hague in 2001 for running a single-issue campaign on Europe. IDS was also hoping to avoid the criticisms that had been levelled at Hague for having a policy that ruled out membership of the euro - but only for the time being. (Such a tactic would also have enabled him to escape the subsequent criticisms levelled at the Howard campaign for its apparent narrow focus on immigration.)

This was also clear in his wider policy shifts. IDS attempted to broaden the party's commitment to issues more commonly associated with parties of the left. 'A Fair Deal for Everyone' (March-June, 2003) suggested that the Conservatives would govern for 'the whole country' and the strategy consciously moved from campaigning on tax, crime, Europe and asylum - issues where the Conservatives were traditionally strong, but which then ranked relatively low down the public's list of salient issues - to pensions, social services, inner-city deprivation, and health and education.

'A Fair Deal for Everyone' was an attempt to get Conservatives talking about their softer side - to make them look less harsh and to challenge the image of them as the 'nasty party' (Theresa May's now infamous observation in her October 2002 Conservative Party Conference speech). It attempted to address the opinion of voters that the Conservative Party stood for the rich rather than ordinary people. As part of the campaign, IDS conducted a programme of visits to some of Britain's most socially deprived inner cities whilst advocating centre-right policies for improving them. Instead of talking about being tough on criminals, the strategy involved 'tough love' solutions to helping them - such as Oliver Letwin's 'conveyer belt to crime' policies increasing spending on young offender and drug addiction programmes. By so doing, the aim was to reposition the Conservatives in the centre ground of British politics, at the same time forcing Labour back onto its heartlands, creating a more equal contest for the centre ground. Thus IDS tried to promote a brand of 'Compassionate Conservativism' 
which would reposition the party and provide Conservatives with a raison d'être beyond merely Thatcherism and Nationalism.

This was a strategy that only a right-winger like IDS could have undertaken (as it was, it attracted considerable criticism from some on the right of the party), but because it didn't fit easily with his reputation as a staunch right-winger or with the media's pigeonholing of the Conservative Party as a right-of-centre party, it did not receive the attention it deserved. It may, of course, be debatable whether he would have been able to continue with such a strategy as the election approached: Hague had variously attempted to 'reach out', as did Howard when first elected leader, only for both to be forced to fall back somewhat onto their relative strengths when faced with an imminent campaign. But it was at least a serious attempt to reposition the party, and one which predated some of the solutions widely discussed after Howard's resignation in 2005.

At times, such efforts at repositioning ran into difficulties with the parliamentary party. For example, in January 2002 the Shadow Cabinet came out in support of a largely elected Second Chamber (to be called the Senate), in which 80 per cent of its 300 members were to be elected, with just 20 per cent appointed. It was the exact opposite of the government's proposals, and, at first, it appeared that the new policy was a tactically sophisticated piece of repositioning, turning the Conservatives into the more 'democratic' party, and outflanking Labour on the issue. The problem for the Conservative leadership was that a belief in the wisdom of the party's position was not shared by all of its parliamentarians. When it came to voting on Lords reform in February 2003, over half the Conservative MPs who voted rejected the position advocated so publicly by the leadership (Cowley and Stuart 2004).

But perhaps the most notable clash came over an issue where (some of) IDS's backbenchers felt he had not repositioned the party enough: the Adoption and Children Bill (see Box 4.1). The rebellion over the Adoption and Children Bill resulted in a renewed focus on the issue of the Conservative leadership, made even more intense when Duncan Smith held a press conference at Conservative Central Office the following day (5 November 2002), during which he claimed that 'for a few, last night's vote was not about adoption but an attempt to challenge my mandate to lead this party'. He then told his party - in one of his few memorable quotes as party leader - that it had to 'unite or die'.

Yet the split - and the subsequent crisis - was almost entirely self-inflicted and eminently avoidable. It is quite common to see occasions when one major party allows a free vote, but the other enforces a whip. But it is almost always the other way round from the Adoption and Children Bill: governments, who need to get their legislation through, often enforce a whip, even if this reveals division, whilst the opposition can allow a free vote, thus disguising any division. This is one - indeed, perhaps the only - luxury of opposition. 


\section{Box 4.1 The Adoption and Children Bill}

The Adoption and Children Bill began life as a fairly uncontentious piece of legislation. But mid-way through its passage it had been amended by backbench Labour MPs to include clauses allowing adoption by unmarried couples. Although the Bill made no distinction between heterosexual or homosexual unmarried couples (and although single gay people were already able to adopt), the issue was thereafter nearly always referred to as one of 'gay adoption' - and it caused division on the Conservative benches.

The government granted its MPs a free vote on the issue. After much discussion in Shadow Cabinet the Conservatives, by contrast, decided to issue a whip, telling the party's MPs to vote against the legislation, although Conservative peers were allowed a free vote. Faced with opposition from a vocal minority of Conservative MPs, the leadership let it be known that they would allow MPs to be absent from the Commons if the issue caused them difficulties (what became known, somewhat oxymoronically, as a 'soft three-line whip').

The issue reached the floor of the Commons in May 2002 and four Conservative MPs defied their party's whip and voted in favour of the legislation. Several others, including four Shadow Cabinet members, found convenient reasons to be absent from the Commons. After amendment in the Lords the Bill then returned to the Commons in November, with more damaging consequences. At the second time of asking, the numbers voting against the whip climbed to eight. A further number of Tory MPs also abstained. In quantitative terms, this was not especially damaging: eight MPs constituted just 5 per cent of the Parliamentary Party. But there was an important qualitative dimension to the Conservative rebels. They included John Bercow, absent from the vote in May but who now resigned from the Shadow Cabinet in order to vote and speak against the party's line. Michael Portillo and Kenneth Clarke - both of whom had stood against IDS when he won the leadership - also voted against their party whip. The other five - David Curry, Julie Kirkbride, Andrew Lansley, Andrew Mackay and Francis Maude - included four former members of the Shadow Cabinet.

Writing in The Times (5 November 2002), Peter Riddell called IDS's decision 'both wrong and tactically inept'. It is not obvious that the first part of Riddell's complaint is valid - in many ways issuing a whip was the more logical and consistent position to take - but the second part is certainly accurate. To impose a three-line whip when there was no pressing need to do so, and when it was clear that there were serious divisions within the party, was crass in the extreme.

\section{The fall of IDS}

Unfortunately for Duncan Smith, there was very little evidence that any of this attempted repositioning did the Conservatives any good with the public. IDS's own polling ratings, for example, were almost consistently poor, bordering on disastrous. Table 4.2 shows the findings of a Populus poll published in January 2003, giving comparisons between IDS and the two other party leaders. On almost every measure, IDS fared the worst of the three, with his scores on being a strong leader (14 per cent) and a good potential Prime Minister (18 per cent) being particularly poor. There were also frequent claims that Central Office kept the results of their focus groups from the leader, so damning was the public's view 
of him and (as Figure 4.1 shows) under his leadership the party still appeared to be flatlining in the opinion polls.

Table 4.2 Views on the party leaders, 2003

\begin{tabular}{lccc}
\hline & $\begin{array}{c}\text { Blair } \\
(\%)\end{array}$ & $\begin{array}{c}\text { IDS } \\
(\%)\end{array}$ & $\begin{array}{c}\text { Kennedy } \\
(\%)\end{array}$ \\
\hline He is a strong leader & 58 & 14 & 43 \\
He understands the problems of people like me & 37 & 29 & 49 \\
He just says whatever he thinks people want to hear & 63 & 47 & 38 \\
I could never vote for that party while he is its leader & 38 & 44 & 28 \\
He is/would be a good Prime Minister & 50 & 18 & 40 \\
\hline
\end{tabular}

Source: Populus/The Times.

As a result of both such poor performances in the polls and some distinctly uninspiring performances by IDS, both at Prime Minister's Questions and in various media interviews, there were persistent rumours about a leadership challenge. Relatively few Conservative MPs (or peers) went public with their criticisms, although discontent surfaced occasionally, such as when Crispin Blunt, the MP for Reigate, described Duncan Smith as 'the handicap of a leader whom Conservatives in Parliament and outside feel unable to present to the electorate as a credible alternative prime minister'. Blunt's timing - coming on the evening that the Conservatives gained more than 500 seats in the 2003 local elections - was somewhat unfortunate (and led to him being widely mocked), but his views were more widely shared than was publicly acknowledged at the time.

Eventually, on 27 October 2003, IDS called on his would-be challengers to 'either bring it on or draw the line' - only to find that they intended to bring it on. The following day it was announced that the requisite 25 signatures of MPs had been delivered to Sir Michael Spicer, the Chairman of the 1922 Committee, to initiate a vote of confidence. And on Wednesday 30 October, IDS lost that vote of confidence by 90 to 75 , a result that was closer than some had predicted, but still an overwhelmingly negative verdict on an incumbent leader. It was, in the end, a breathtakingly quick defenestration. With equally breathtaking speed, Michael Howard then appeared as the 'unity' candidate for the leadership. All the potential rival candidates declared that they would be supporting Howard. With just one candidate, there was no need for a ballot of MPs, let alone the grassroots, and Howard became party leader.

The whole process had been initiated, and then decided, by the party's MPs, within less than a week, with no grassroots involvement at all. Parliamentarians remain in an extraordinarily privileged position in most British political parties - and nowhere is that more obvious than in the Conservative Party. 


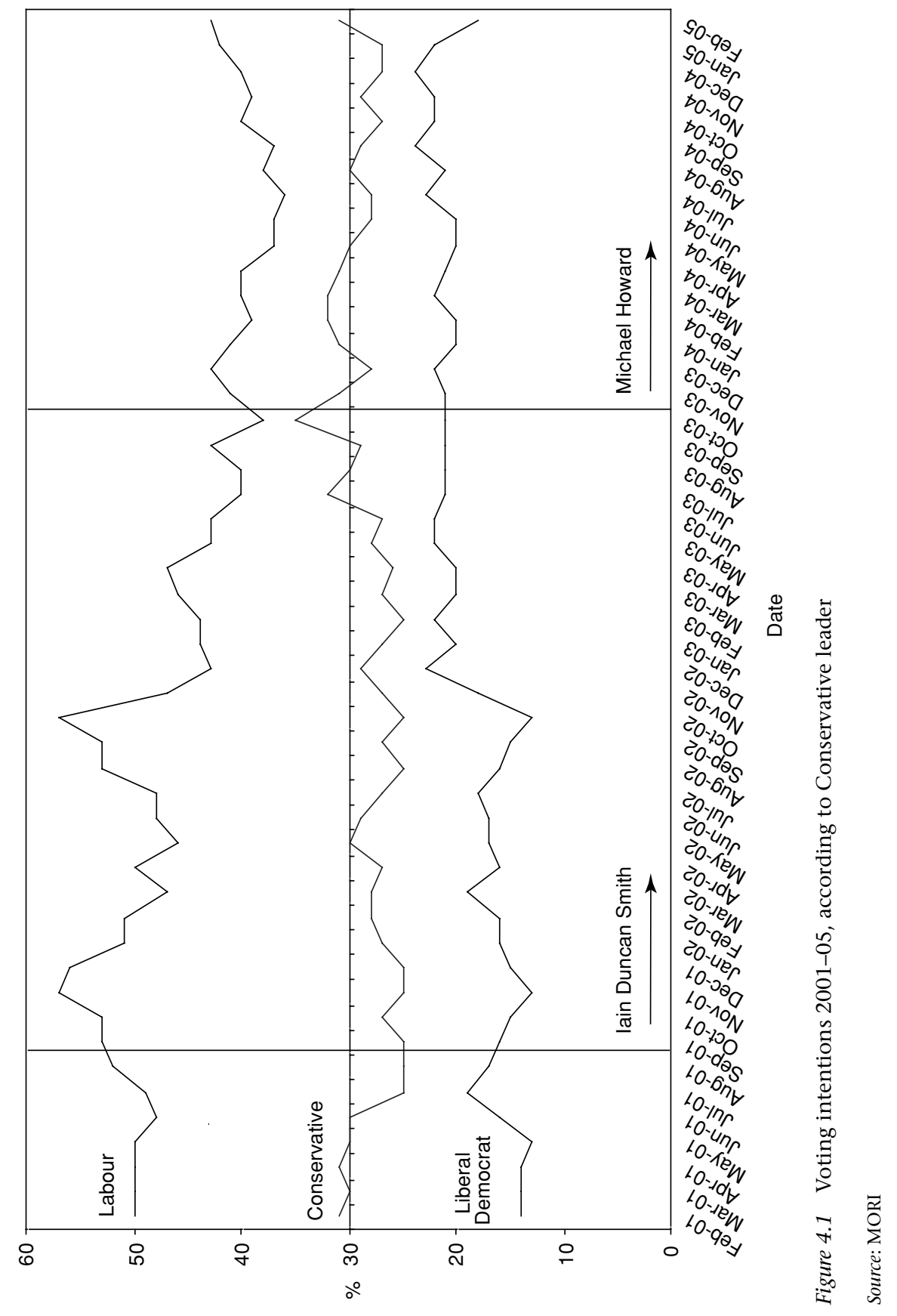




\section{The party under Howard}

Michael Howard's assumption of the leadership appeared to transform the Conservative Party. It seemed to acquire some vim and vigour. Howard's appearances at Prime Minister's Questions were substantially better than those of IDS, with the result that Howard bettered Blair frequently. When he was on form - as with his charge that as a grammar school boy he would be taking no lessons on education from a public school educated Prime Minister - he landed blows way beyond those IDS could have dreamt of, with the result that his backbenchers were enthused almost overnight. His one conference speech made as party leader before the 2005 election was also much better received. Howard's performances also helped bring back into the fold influential financial donors - several of whom had stopped giving money whilst IDS was party leader - and helped reinvigorate the grassroots membership of the party.

One reason for this last point was that Howard was rated much more highly by Conservative supporters than either of his predecessors had been. As Figure 4.2 shows, both William Hague and Iain Duncan Smith had been viewed negatively even by Conservative supporters, with more dissatisfied than satisfied by their performance.

The exception - as is clear from Figure 4.2 - was IDS early on in his period as leader in 2002, when many Conservative supporters instead said that they didn't know how to judge him. Once Conservative supporters got to know IDS, then his ratings also became negative, just as Hague's had been. Whereas for every Conservative supporter dissatisfied with Howard, there were two who were satisfied with his performance.

The public also saw differences between the two leaders. Howard was more likely to be rated as understanding the world's problems, understanding the problems facing Britain and as a capable leader. But he was also more likely than IDS to be perceived as being rather narrow, tending to talk down to people, inflexible, and, most of all, out of touch with ordinary people. ${ }^{1}$

And there was also little obvious sign that the Conservative Party overall poll ratings improved under Howard's leadership. Despite an initial boost when he became leader, the Conservative Party failed to move significantly above its 30 per cent plateau in the opinion polls under Howard, just as it had done under IDS (see Figure 4.1). And whilst Howard may have been liked by Conservative supporters, his ratings with members of the general public (see Figure 4.3) were almost as poor as those of IDS. His overall satisfaction ratings with members of the public were almost uniformly negative: that is, more people said that they were dissatisfied with him than were satisfied.

However, leader evaluations are driven by perceptions of the party just as perceptions of the party are driven by perceptions of the leader (see Andersen and Evans 2003). The problem for the Conservative Party 


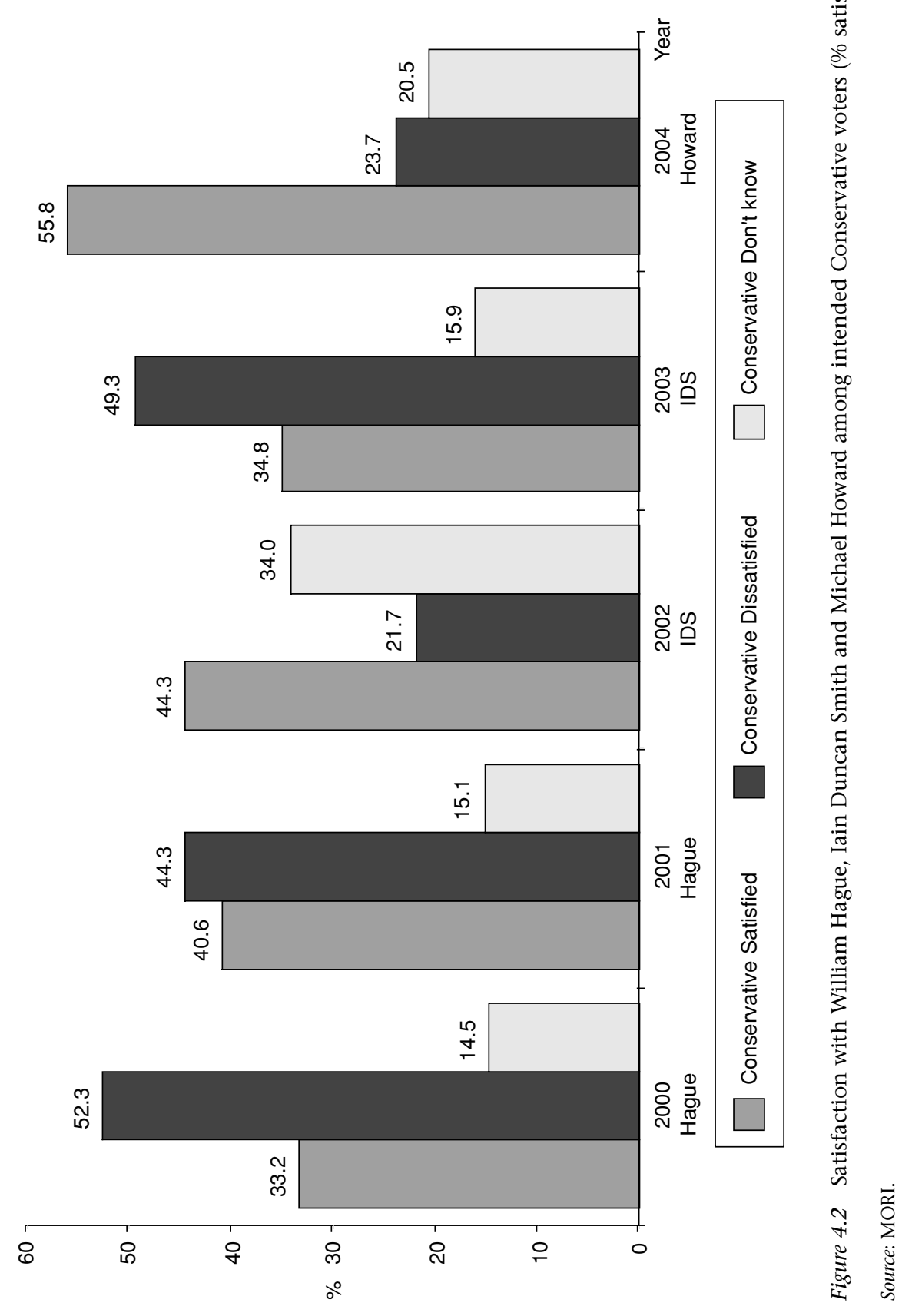




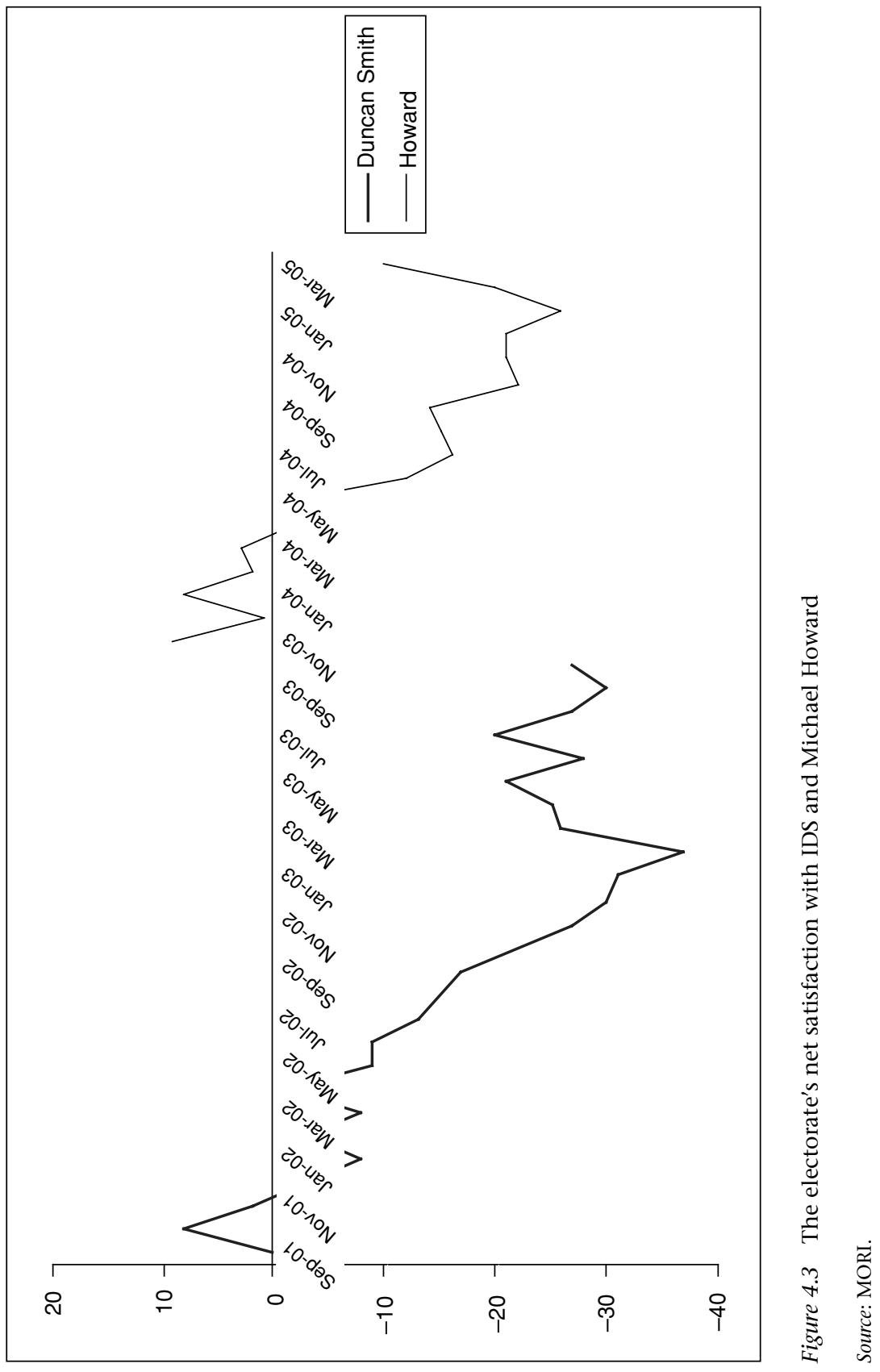


throughout this period remained its inability to shift significantly from poll ratings of 30 per cent or just above - a situation it has now been stuck in since late 1992 - regardless of who has been in charge.

\section{The Conservative approach}

The overall Conservative strategy for the general election was predicated upon two pieces of knowledge. First, that the public did not think very highly of the government. Second, the party also knew that if instead of asking people to judge the government you asked them to choose between Labour and the Conservatives, they chose Labour. ${ }^{2}$ Similarly, who did people think would make the better Prime Minister - Blair or Howard? Answer: Blair. The Prime Minister's ratings may have taken a knock over the last four years, but he was still preferred to Michael Howard. ${ }^{3}$ One reason for this was that whilst people didn't think much of Labour, they had equally low, or lower, expectations of what a Conservative government would deliver. This meant that there was relatively little value in the Conservatives presenting themselves as an alternative government, because it was not an outcome that many people anticipated or relished. But there was value in presenting the party as a vehicle through which Tony Blair could be given a bit of a kicking.

This lay behind much of the Conservative language used in posters and adverts. For example, these are the words used by Michael Howard when launching the Conservative manifesto:

Imagine waking up on May the sixth to see Mr Blair re-elected. Imagine how you'd feel. You don't have to settle for that. Use your vote to tell Mr Blair that it's just not good enough. Use your vote to take a stand.

Similar words were then used almost consistently until the election. The following (all from Michael Howard) are just illustrative examples rather than a comprehensive list:

- So if you think that crime's too high, our asylum system is out of control and $\mathrm{Mr}$ Blair has hit you with too many stealth taxes - then you need to send him a very clear message. Enough is enough. (15 April 2005)

- Students cannot afford any more stealth taxes. They can either reward $\mathrm{Mr}$ Blair for eight years of broken promises, and vote for another five years of talk. Or they can vote Conservative, to support a party that's taken a stand and is committed to action on the issues that matter to hard working Britons. (21 April 2005)

- If you stay silent, you will send him a clear message: 'Carry on, you're doing just fine'. (23 April 2005) 
- Why don't you take a stand? Isn't it your duty to take a stand? Your duty to yourselves and your duty to our country. So think carefully about the message you want to send. In twelve days time, you have the chance to take a stand - in fact it'll be your last chance to take a stand on Mr Blair. (23 April 2005)

All of these messages indicated that the election was a chance for voters to 'take a stand', and to 'send Tony Blair a message' by 'supporting' (but never by 'electing') the Conservatives. The unspoken implication of the latter was that Labour would still be in power after the election, and so it was especially important to use the election to send a message to the Prime Minister. A similar message came in Howard's comparison of the election to a football match in which one team was 2-0 down at half time (although the comparison was made in the context of teams being able to come back from 2-0 down). ${ }^{4}$ The aim of such tactics was to depress the Labour vote (by appearing, at least de facto, to accept that Labour were going to win the election) whilst encouraging Conservative voters to turn out to send their message.

The Conservatives did occasionally talk about what they would do if elected to government, but such references were less common and were very carefully framed. The party knew that the electorate was highly disenchanted and turned off by Westminster village politics. Trust for politicians was low, many voters couldn't tell the difference between the parties, few people knew what the Conservative Party stood for, many people thought the party out of touch with the problems facing the country, and a general disillusionment with political rhetoric had taken root. Therefore the tactic chosen by the Conservatives was 'action not words' and a simplified message - so simple it initially involved only ten words - on 'the issues that matter': 'more police, cleaner hospitals, lower taxes, school discipline, controlled immigration'. ('Accountability' was later added to the list.) At times, it was like listening to a focus group recording being played back to the electorate. 'What do people say about Labour? They're all talk. What will the Conservatives do? Less talk. More action.' Hence when the party did talk about tasks for a Conservative government, they all had a set time frame. For example, within the first day, the Conservatives would set out plans to give head teachers the power to expel disruptive pupils and they would set a date on the referendum on the European Constitution to campaign for a ' $\mathrm{No}^{\prime}$ vote. Within the first month they would start the recruitment of an extra 5,000 police officers each year, bring back matrons to take charge and deliver clean and infection-free hospital wards, introduce a waste-cutting budget and set in train 24-hour surveillance at ports of entry to Britain.

Much of this was similar to tactics used by the Conservative strategist, Lynton Crosby, an Australian brought in by Howard to mastermind the Conservative campaign. Crosby had been involved in several campaigns in Australia in which 
the opposition sought to give the impression that they could not win, and to encourage people to use their vote as a protest or a way of sending a message. Three specific phrases - 'enough is enough', 'send a message' and 'take a stand' were all direct imports.

Another Crosby tactic was a relentless focus on the marginal seats. Crosby once argued that 'targeting has become the key to electoral activity. Focusing on the seats that are critical, focusing on the people within those seats who are critical, and focussing on the critical issues within those seats', and in 2005 the Conservatives' targeting of marginal seats was regimental. The party expanded its target seat list to demonstrate confidence going into the election, and some money was spent on seats where they had a minimal chance of success, but the most marginal seats received relentless attention.

On Crosby's arrival, the Conservatives established a campaigning nerve centre for target seats, Constituency Campaign Services (CCS), in Coleshill, Birmingham (the location was itself said to be a statement of the party's determination to redirect its focus away from the South of England). Candidates could get support as and when needed, and were provided with a more professional array of centrally designed resources. Furthermore, with Coleshill came the innovation of a more sophisticated direct marketing database 'Votervault', apparently procured by the Party Chair, Dr Liam Fox, from the US. Votervault used consumer-based 'Mosaic' data combined with locally held canvassing returns to predict voters' intentions. This enabled the party to send targeted messages to key individuals in marginal constituencies, also enabling the party to spend precious campaign resources centrally (thus relieving candidates of pressure on their controlled campaign expenditures). These direct mailshots were complemented by the Geneva call centre in the newly situated Conservative Campaign Headquarters in Victoria Street, London, from which volunteers spoke to hundreds of thousands of voters. ${ }^{5}$ These efforts were directed at just over 800,000 voters in around 100 constituencies. It left the rest of the country feeling like the general election campaign was happening on a distant planet whilst leaving targeted voters deluged. The eventual increase in the Conservative vote between 2001 and 2005 was about half the number targeted, at just over 410,000.

\section{Conservative strengths - and weaknesses}

Much controversy surrounded the choice of Conservative campaign issues specifically the party's focus on immigration. But the Conservatives had little choice. In 2005, the Conservative Party had two advantages which were absent in 2001. The first was the self-evidently weakened Labour support caused by a loss of trust in the Prime Minister and general disillusionment with Labour. But the second was a significant increase in the salience of an issue on which the Conservatives were judged the best party. 
Figure 4.4 shows which party was considered best able to handle issues considered to be important problems, listed in order of Conservative advantage relative to Labour. ${ }^{6}$ The Conservatives led on five issues - asylum and immigration, defence, crime, Europe and taxation - whilst Labour led on the other five. This was actually a very similar set of rankings to those four years before. But four years before, the problem for the Conservatives had been that those issues where the public thought the Conservatives were strong, the public also judged largely unimportant, whereas on issues that the public thought important, they trusted Labour (Cowley and Quayle 2001: 58).

What had changed over the preceding four years was that in 2005 the public saw one of these issues - asylum and immigration - as far more important than they had four years before. Figure 4.5 shows the striking increase in the number of people claiming that asylum and immigration was 'the most important problem facing the country today'. For much of the 2001 Parliament, asylum and immigration was considered to be as important an issue as education and (at times) more important even than health care. It was, therefore, hardly surprising that the Conservative Party made asylum and immigration one of their campaign slogans. By focusing on this issue the Conservatives' strategy was consistent with saliency theory: to raise the salience of your own issue strengths and neutralise or downplay the strengths of your opponent (Budge and Farlie 1977). As one Conservative advert said apropos something else entirely: it's hardly rocket science, is it?

It was often said that by doing so the Conservatives were targeting their 'core vote' - but this is too simplistic a claim. Conservative voters were, in fact, only 3 per cent or 4 per cent more likely to rate this issue as the most important, when compared to undecided voters. The image of hordes of Conservative voters, all foaming at the mouth and morbidly obsessed by immigration, is a caricature. The Conservative 'core vote' has pretty much the same interests and priorities as most other voters. The policy was designed to help stave off the threat posed to the party by UKIP. The first test of Michael Howard's leadership had come in the European elections on 10 June 2004; and they had been a disaster for the Conservatives. The Tories achieved only 27 per cent of the vote, dropping almost nine percentage points since 1999. By contrast, UKIP's vote share increased from 7 per cent in 1999 to just over 16 per cent in 2004. The UKIP surge was a worrying signal to the Conservatives that even their core vote could desert them, and the period was one of deep dismay at Central Office. Polling evidence in Central Office showed that UKIP voters were not noticeably more Eurosceptic than other Conservative voters - but they were particularly motivated by immigration. The party's stance on immigration was therefore as much about fighting off the UKIP threat as it was about engaging with Labour or the Liberal Democrats; KilroySilk's departure from UKIP (to set up his own party, Veritas) was one of the best 


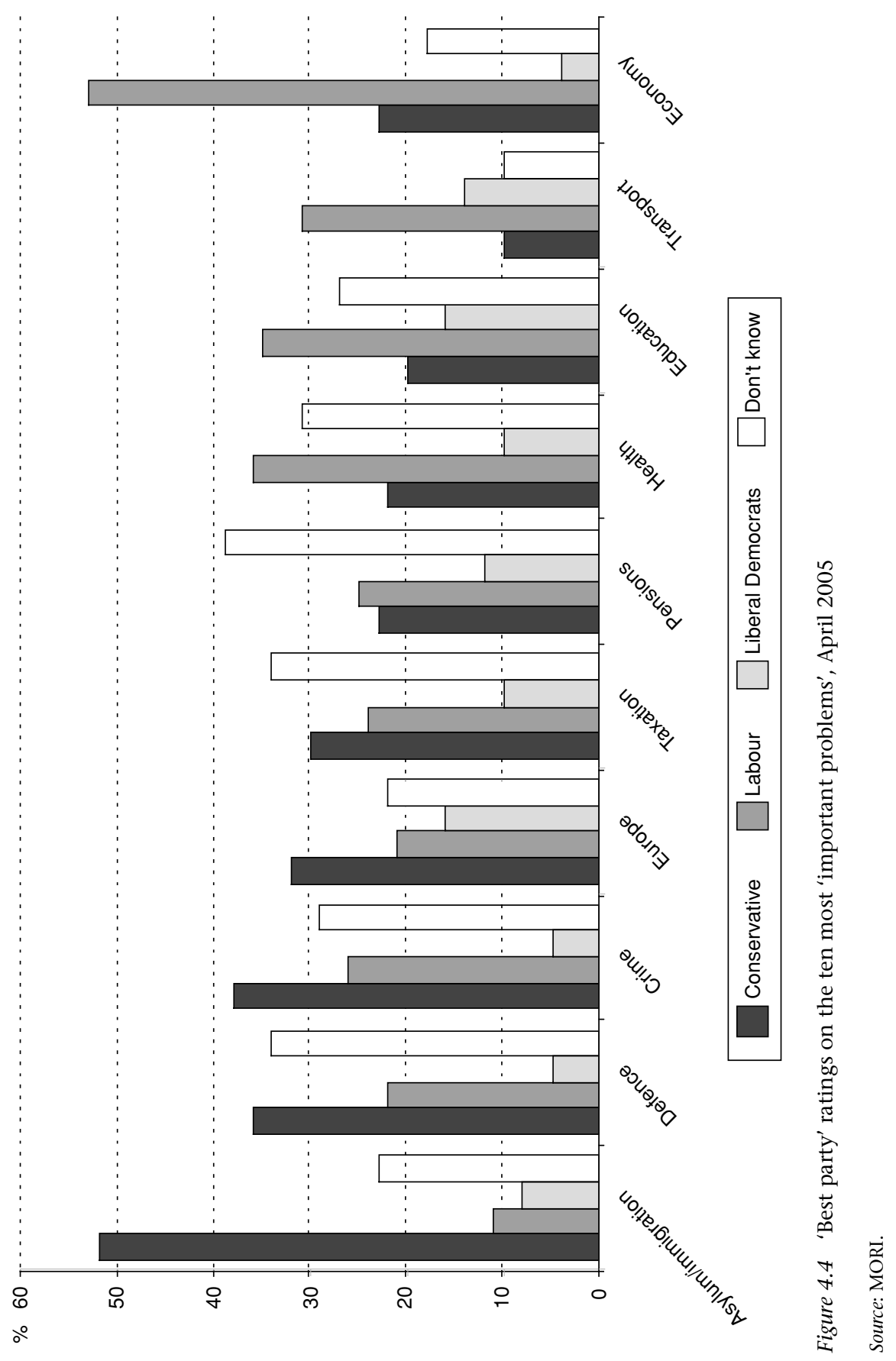




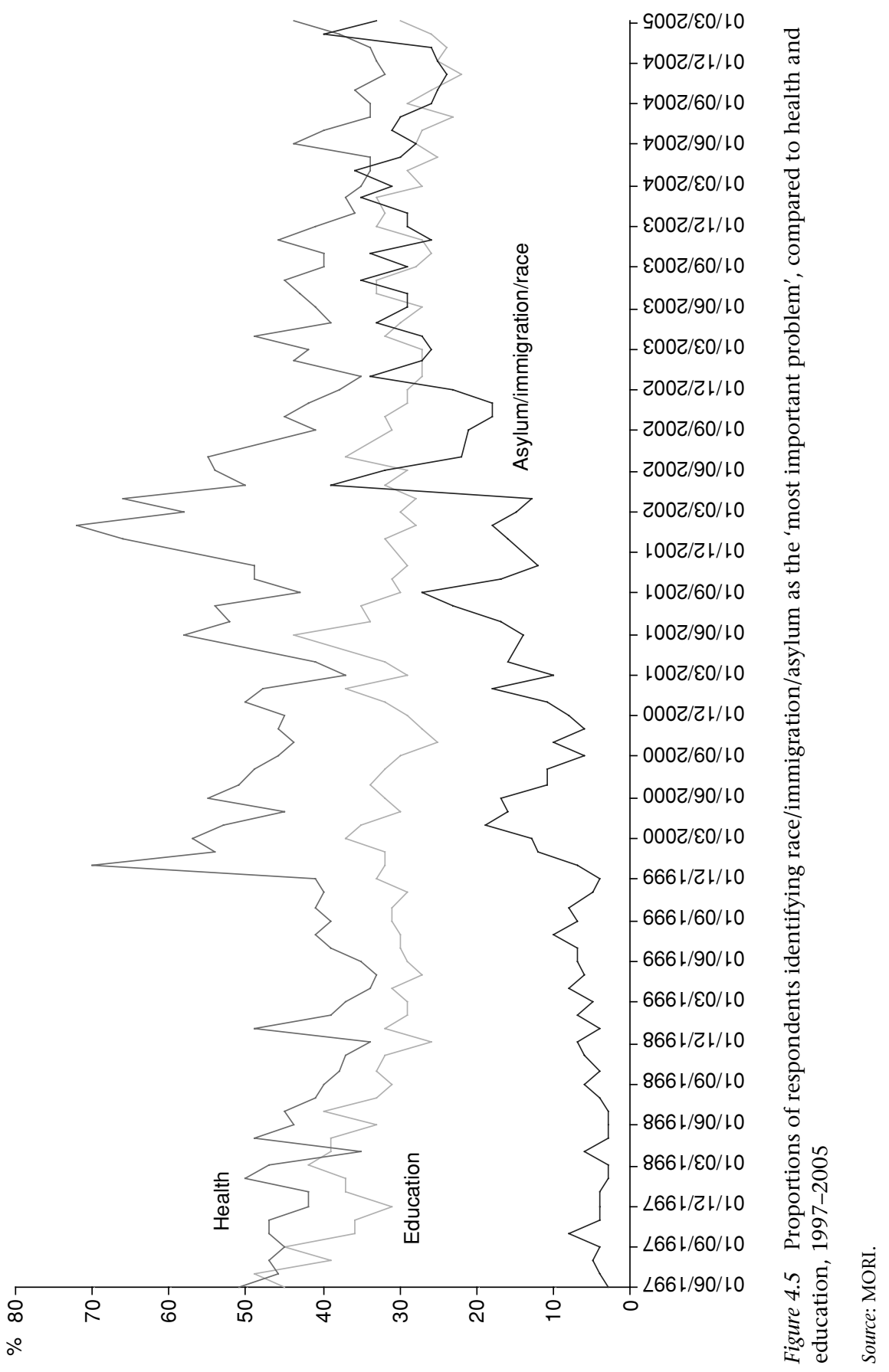

64 


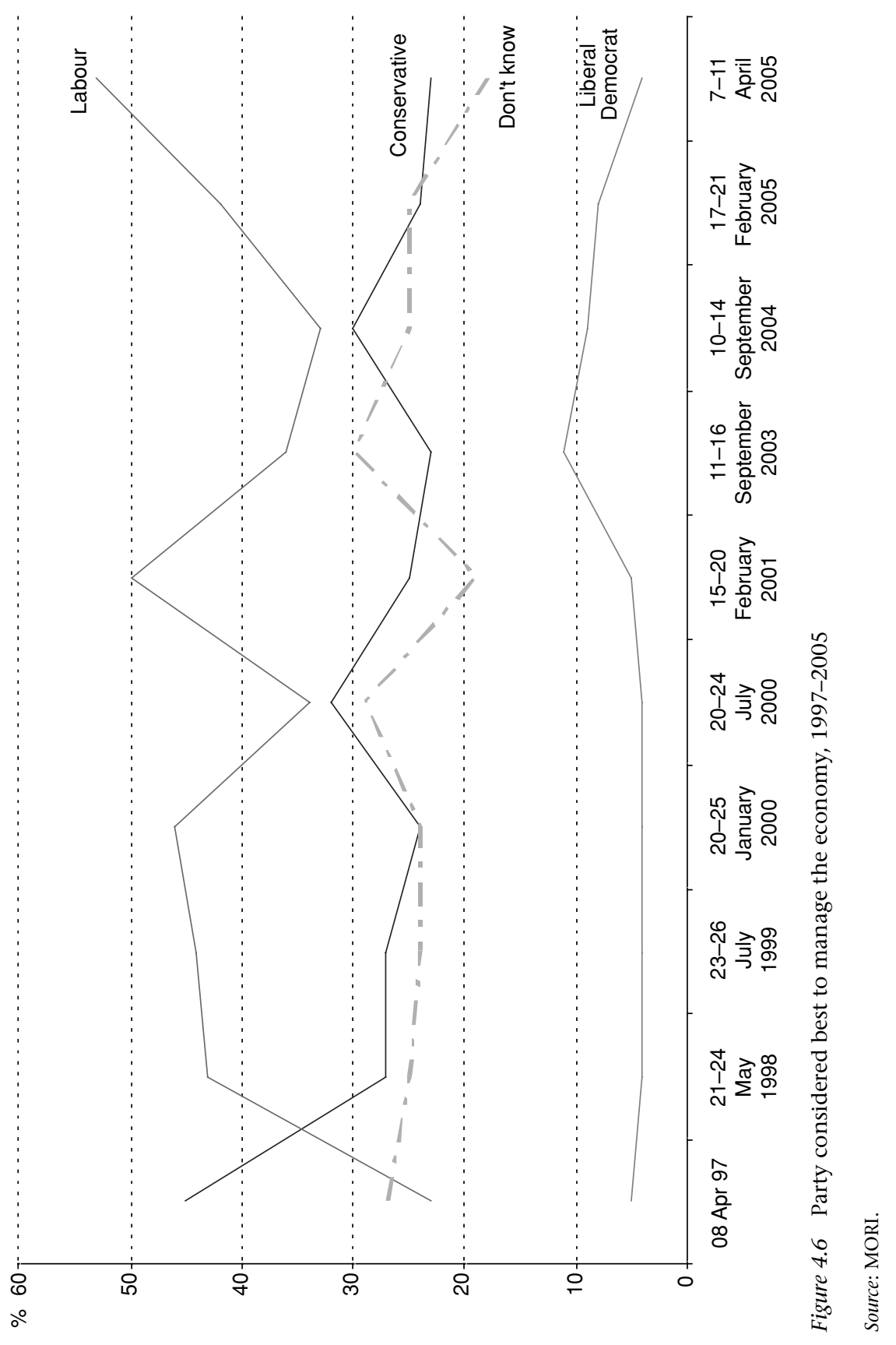

65 
pieces of news to arrive on Michael Howard's desk in the planning stages of the general election campaign.

The polling data also show one serious continuing weakness for the Conservatives. Of the ten issues listed as important problems or important in deciding how to vote, the economy was the one where the Conservatives were judged furthest behind Labour; and as the election approached (see Figure 4.6), Labour's advantage on this crucial issue increased, leaving the Conservatives even further behind. The overriding problem for the Conservative Party therefore was this: despite 13 years passing since 1992 when Black Wednesday resulted in plummeting poll ratings, the Conservatives have failed to demonstrably improve their position on this key issue. This is such a reversal of the normal state of British politics (prior to 1992) that it now sometimes goes without comment - but since 1992 the Tories have fought three elections in which they have been without the trump card that they used to be able to deploy so successfully throughout most of the twentieth century. Hence one of the key battles in the campaign was which party would shape the agenda onto or away from the economy.

\section{Conclusion}

By the end of 2005, it is likely that the Conservative Party will have elected their fifth leader in 15 years. If the period from 2001 to 2005 teaches them anything, it is that changing the leader is, on its own, not enough to solve the problems the party faces; and that short-term fixes are no substitute for long-term change.

There is little doubt that the replacement of Iain Duncan Smith with Michael Howard reinvigorated the party, but it also had its costs. The belief that a change in leadership was sufficient - and that the arrival of Michael Howard would therefore be enough to restore the party's fortunes - meant that the party avoided the big issues that remained associated with the party's image. The process of examination that Iain Duncan Smith began, at least hesitatingly, may be painful, but it remains essential. The lesson from 2001-05 is that simply changing the leadership - and/or importing clever campaigning tactics - will not be enough. New leaders are simply faced by the same old problems.

The reliance of the Conservatives on their loyal base has only staved off disaster because the Conservatives have been contesting relatively low-turnout elections. Any new leader must address ways of reaching beyond the third of the electorate who voted Conservative in the last three elections - beyond core voters in the countryside and in the south and east of England and out into the urban areas and the Celtic fringe, where levels of Conservative support is currently dismal.

Yet one of the greatest difficulties for any new leader is that new solutions are hard to find. Just as replacing a leader is not enough, there is similarly no magic bullet for Conservative strategists. The Conservatives remain stuck between a rock and a hard place. If they campaign on their strengths they reinforce old 
images of the party. If they campaign on Labour's issues - issues which also enjoy higher salience with the public - they risk damaging the party even more in the short term. The challenge is to grow the range of relative strengths, but until the party's image improves, and until they resist the temptation of focusing only on imminent campaigns, it is unlikely that the party will be seen as more likeable or more competent on the issues that matter to most people.

It is also difficult to overstate the damage done to the Conservative by their loss of reputation on the economy - and, concomitantly, by Labour's lead on this key issue. This is only likely to be reversed when the present government's record on the economy turns sour via some sort of recession. The Conservative MP John Bercow is right that the Conservatives can't afford to wait for the economy to fail - but that may still represent one of their best chances of regaining power.

The Conservative Party is, as we write, embarking on a potentially divisive disagreement on the required depth, breadth and meaning of its 'modernisation'. Such reform is hard to sustain for two reasons. First, because Blair has successfully occupied much of the Tories' traditional policy space for over a decade and it has proved extremely difficult for the Conservatives to repel these boarders. And second, many traditionalist Conservatives (both MPs and members alike) do not believe such changes are necessary. For all the talk of a large influx of modernisers among the 2005 intake, they still constitute a minority in the parliamentary Conservative party: for every Michael Gove, there is an Andrew Rosindell. Any attempts at radical change could simply result in renewed factional infighting between the 'mods' and 'rockers' within the party, which is unlikely to help it regain power.

\section{Notes}

1. As the Conservative Party campaigned, so Howard's own evaluations altered; his positive attributes became more positive, whilst his negative attributes became more negative. So, whereas between 2004 and 2005 Howard improved on ratings of understanding the world's problems (from 9 per cent saying so in 2004 to 12 per cent in 2005), understanding the problems facing Britain (from 17 per cent to 21 per cent) and being seen as a capable leader (15 to 18 per cent), he was also more likely to be perceived as being rather narrow minded ( 13 to 22 per cent), tending to talk down to people (17 to 22 per cent), and be out of touch with ordinary people ( 22 to 30 per cent).

2. The precise statistics varied, depending on the polling company, the question used, and the timing - but figures of around 50 per cent (Labour) to 35 per cent (Conservative) were not unusual. When people were given a slightly more nuanced choice, around a quarter would choose a hung Parliament, but even then those who'd prefer Labour to win outnumbered the Conservatives.

3. Again, the precise figures varied - but a ratio of 40 per cent (Blair) to 25 per cent (Howard) was not unusual.

4. Specifically, Howard was discussing the Carling Cup final, in which Liverpool (one of the several football teams Howard supports - along with Folkestone Invicta, Swansea 
City and Llanelli) had been leading 2-0 only to lose. The interview in which he made this observation was also the first time (to our knowledge) that any party leader has used the word 'screwed' (in anything other than its purely mechanical meaning) whilst campaigning to be Prime Minister: 'we were ahead until the last 10 minutes and then we got screwed'.

5. One of Michael Howard's first decisions as leader was to move the party headquarters from Smith Square to the more modern and less maze-like Victoria Street offices. As well as a cost-saving measure, the move was an attempt to end the old Central Office culture and turf wars.

6. Respondents choosing an issue as the most important then choose which party would handle the problem best. The proportions rating the issues as the most important problem varied only marginally depending on which party respondents favoured.

\section{References}

Andersen, R. and Evans, G. (2003) 'Who Blairs wins? Leadership and voting in the 2001 election', British Elections and Parties Review, 13.

Budge, I. and Farlie, D. (1977), Voting and Party Competition: A Theoretical Critique and Synthesis Applied to Surveys From Ten Democracies, London: John Wiley.

Cowley, P. and Quayle, S. (2001) 'The Conservatives: running on the spot', in A. Geddes and J. Tonge (eds) Labour's Second Landslide, Manchester: Manchester University Press. Cowley, P. and Stuart, M. (2004) 'Still causing trouble?', Political Quarterly, 75.

Walters, S. (2001) Tory Wars, London: Politicos. 


\section{Enfield Southgate}

Were you still up for Stephen Twigg? The question was a predictable response to the downfall of the Labour candidate who had famously ousted potential Conservative leader Michael Portillo in 1997 and prompted a book title. As Twigg's victory in 1997 symbolised the arrival of New Labour and Blairism, so his defeat in 2005 indicated a turning of the electoral tide, a potential peaking of the Blair project.

Like Portillo, Twigg accepted defeat with dignity. Similarly, Twigg, a Labour minister, had not anticipated defeat. Although Enfield Southgate was never going to become a safe Labour seat, it appeared that Twigg had nurtured the seat sufficiently to prevent anything like the 6.6 per cent swing needed by the Conservatives for its recapture. Given that there had been a 5 per cent swing in Labour's favour in 2001 and the party had won an overall majority of the vote, it appeared the seat was secure for at least one more election. Twigg ruefully conceded a few days after the 2005 verdict that 'The first I knew I was in trouble was when the telly said so' (The Times, 13 May 2005).

Enfield Southgate provided one of several Conservative gains in the South East, where a strong revival was underway. The seats 'loaned' to Labour in 1997 and 2001 began to return, as 4,644 voters deserted the party. Meanwhile Portillo texted Twigg with some helpful advice: 'I recommend a by-election' (The Times, 13 May 2005).

Result

Burrowes, D. (Con)

Twigg, S. (Lab)

Kakoulakis, Z. (LD)

Doughty, T. (Green)

Hall, B. (UKIP)

18,830

17,083

44.6

$4,724 \quad 11.2$

$1,083 \quad 2.5$

$490 \quad 1.2$

Con gain from $L a b$

Con majority

1,747

4.1

Swing: Lab to Con

Turnout: $66.4 \%$ 